\title{
Hanoi's early 20th century: “On the second floor - Phố Phái”
}

\author{
Ho Manh Toan \\ Phenikaa University \\ Hoang Phuong Hanh \\ Vietnam National Institute of Educational Science \\ Vuong Thu Trang \\ Sciences Po Paris
}

Hanoi, September 22, 2019

Whenever he had spare time, Artist Bùi Xuân Phái used to gather with friends at Lâm Café, where he sought inspiration to depict Hanoi. Being an original Hanoian, the artist had had a strong attachment with the old quarter area since childhood. It was amidst the peace from within that he was able to "grasp" the exotic charm of Nguyễn Dynasty architecture slanted houses with sagged roofs and protruded gables.

Even though he originally based his artworks on real scenes, Bùi Xuân Phái's later pieces were solely from memory. That is why his paintings of the old streets of Hanoi are relentlessly alluring with a sense of vintages and nostalgia despite the fact that most of them are monochromatic with chaste and transparent brushstrokes. Later on, one of the most famous 20th century Vietnamese writers, Nguyễn Tuân, has coined the word "Phái Phố" - a play on the artist's given name ("Phái"), the word street in Vietnamese ("phố") and the ancient name of Hội An "Phai Phô" -to refer to the paintings of Bùi Xuân Phái. This peculiar portmanteau gradually became a sort of "brand name" and grew to become its own concept.

It is hard to construe the nostalgic sense emanating from the old streets of Hanoi in Bùi Xuân Phái's paintings. How could those lines and shapes evoke such vivid emotions? The artistry and mystery of Phố Phái were even able to touch the foreign guests from the far West [1].

Towards the time of the Lunar New Year celebrations, which hover around late January to mid-February in the Gregorian calendar, the old streets of Hanoi are often flooded with peach blossom markets and flocks of pedestrians sightseeing and shopping for the biggest festival during the year. Stores are coated in the color of Tết - red, convivial shades of red, from pale reddish peach blossoms to red couplet banners and red envelopes. The ancient splendor of Hanoi is hidden behind the bustling red field. One has to look to be able to notice the quiet culture nestled still in the middle of the day-by-day modernized Hanoi.

And not just look; one needs to know where to look as well. In this case: look upwards, on the second floor of the old townhouses, which has not been replaced by showcasing pavilions or modern glass doors. Some houses have been repainted, but the architecture - the form of the story, the shapes, and construction of the balconies, the decorating sculptures - still exudes a century-old familiarity. So it turns out that Phố Phái, though no longer intact, is still present here. 
Observing the aforementioned hidden culture and its preservation, a new research study has been conducted. The project wrapped up just before the Lunar New Year of 2019. 'Cultural evolution in Vietnam's early 20th century: a Bayesian networks analysis of FrancoChinese house designs' was completed on January 26, 2019 and published as a preprint version on OSF, SocArxiv, and SSRN.

By September 4, 2019, the study had successfully gone through the peer-review process and was published in Social Sciences and Humanities Open [2]. The article is the first publication of an open-access publication covering the entire social sciences and humanities by Elsevier.

The house bears a deep meaning to every Vietnamese. It is in fact not a mere physical building but often the material embodiment of the home, which is best illustrated during New Year's days when people stream to their hometown for Tết reunion with family despite their everyday tight working schedule. The house also represents a valuable family asset across many generations. As such, every aspect of the house could be considered meaningful - including aesthetics. Given how the values of the three religions, especially Confucianism, are deeply instilled in the life Vietnamese families, the construction of the house and the interior design are therefore not merely a matter of architecture, but also reflect the perceptions and beliefs held by the family. Then, the beginning of the 20th century witnessed the interrelation and ambiguity among Vietnamese cultural origin of the Chinese Three Religions and the newly infused French culture. Therefore, house architecture under this period treasured the Vietnamese soul torn between two value systems: the conservative Confucians and the contemporary French-speaking intellectuals.

Based on photographs of the façades of 68 old street houses in Hanoi, the research team has coded typical features that could signify the stage of cultural evolution that the architecture reflects: newly started, ongoing, or completed cultural. The data were then analyzed using Bayesian networks in order to answer two questions:

- Is it possible to base on the aesthetic sense, architecture, and design of these houses to detect traces of cultural evolution in the early 20th century in Vietnam?

- What factors have the greatest impact on the perception of the cultural evolution process of Vietnamese people, who are frequently exposed to these architectural designs and cultural behaviors?

First of all, the research has demonstrated that humanistic studies can make full use of modern statistical techniques. The study employed a medium-sized sample data, constructed highly representative variables, and applied powerful techniques of Bayesian network, taking advantage of both frequentist and Hamiltonian Markov chain Monte Carlo (MCMC) approaches, to confirm the feasibility of detecting the cultural evolution process based solely on quantitative assessment of aesthetic elements, namely the architecture and design of the façades of ancient houses. The use of Bayesian statistics in the domain of social sciences and humanities has precedence: for example, a study published in Palgrave Communications has conceptualized the phenomenon of cultural additivity based on the study and quantification of Vietnamese folktales [3]. Researchers hope that this new methodological approach will contribute to new findings in the fields of cultural studies, anthropology, and history. 
In response to the second question, the study pointed out the strong influence of Buddhist elements mirrored on Vietnamese ancient home façades. Typical symbols and features such as lotus, chrysanthemum, and wheel of reincarnation were skillfully integrated into the house fronts. Although not easy to recognize, the availability of Buddhist elements made the décor of the typical house in Chinese or a cross between French and Chinese styles. Hybrid décor also represents the highest probability of the ongoing cultural evolution process.

The pictures were captured in the early mornings or on tranquil New Year's days again raised key questions about the process of cultural evolution in Vietnam. The houses that remain untouched, also the most likely to boast a second floor whose architecture reflects completed cultural evolution, are rare. Old houses are gradually being demolished. There is even an originally communal house which will soon be replaced by a supermarket.

Longing for traditional values that are to be washed away, poet Vũ Đình Liên once wrote:

\section{Nhưng mỗi năm mỗi vắng \\ Người thuê viết nay đâu? \\ Giấy đỏ buồn không thắm}

Mực đọng trong nghiên sầu.

(Vũ Đình Liên, 1936)
But fewer buyers came each year

Admirers, where did they go...?

Unused ink laid like black tears.

Red paper dulled in sorrow.

The poetic verse belongs to the famous poem The Calligrapher (1936), with various English translated versions compiled by Phạm Trọng Lệ in his research on the meaning of Tết with the Vietnamese [4]. Back in the days, calligraphers were often teachers of Chinese literature and well-respected intellectuals in a society where literacy was low. Plus, being able to write Chinese characters was one thing; being able to write them skillfully and beautifully was another matter altogether and often required years of practice that most of the population, even when perhaps literate, could not afford. The role of calligraphers was emphasized the most during Tet celebrations, with the tradition of hanging Chinese couplets and decorating the house with certain ideograms that represent well-wishes (happiness, prosperity, fertility, etc.) or personal qualities (talent, patience, compassion, etc.). However, their significance came to be greatly undermined as Han characters were replaced by the Latin alphabet, and the society gradually westernized itself under French colonial rule. Even the teaching of Chinese writing and literature was no longer viable as a job, never mind calligraphy; calligraphers struggled, dwindled, and ultimately gave up the craft as a professional job [5].

Today, the tradition of going to calligraphers during Lunar New Year celebration remains vivid, though the craft of calligraphy is nowhere as widespread or lucrative. People visit the Temple of Literature (Văn Miếu) at the beginning of the year to ask for Chinese characters. Some ask for the word Xue (學 - Study) with the desire for good examination 
results, others opt for the word Lu (禄 - Luck), hoping for a new year full of fortune, a scent of Vietnamese culture fortunate enough to be preserved and continued in the present day.

And this is a significant parallel to the architecture narrative. As new mansions and building blocks emerge and gradually replace ancient houses, what is to become of the artifacts of past culture, in which cultural evolution has been crystallized? The greatest value of these pictures, paintings, datasets, and this research lies in how scientific writing preserves disappearing worlds.

\section{References:}

[1] Vuong, Q.H., Ho, M.T., Vuong, T.T., Tran, K., \& Ho, M. T. (2018b). "Paintings can be forged, but not feeling": Vietnamese art-Market, fraud, and value. Arts, 7(4), 62, DOI: 10.3390/arts7040062.

[2] Vuong, Q. H., Khiem, B. Q., La, V. P., Vuong, T. T., Ho, T. M., Nguyen, H. T., ... Ho, T. M. (2019). Cultural evolution in Vietnam's early 20th century: a Bayesian networks analysis of Hanoi Franco-Chinese house designs. Social Sciences and Humanities Open, 1(1), 100001, DOI: 10.1016/j.ssaho.2019.100001.

[3] Vuong Q.H., La V.P., Vuong T.T., Nguyen V.H., Ho M.T., Nguyen T.H.K., Bui Q.K., Ho M.T. (2018). Cultural additivity: Behavioural insights from the interaction of Confucianism, Buddhism, and Taoism in folktales. Palgrave Communications, 4, DOl: 10.1057/s41599-018-0189-2.

[4] Phạm, T. L. (2018). The meaning of Tết in Vietnam. The Firmament Literacy Journal, 10(4), 8-18.

[5] Nguyễn, T. (2013). Khoa thi cuối cùng. In: Nguyễn Tuân (ed.) Vang Bóng Một Thời (pp. 331). Hanoi: NXB Văn học. 